\title{
Sosialisasi Pemanfaatan Media Sosial Pada Masyarakat Pedesaan Terhadap Kemajuan Pendidikan Islam
}

\author{
Irma Yanti \\ Program studi Pendidikan Agama Islam, STAI DR. KH. EZ. Muttaqien Purwakarta \\ e-mail: irmayantijelek@gmail.com
}

DOI: https://doi.org/10.52593/svs.01.1.05 Naskah diterima: 17 Desember 2020, direvisi: 29 Desember 2020, disetujui: 14 Januari 2021

\begin{tabular}{ll}
\hline Abstraksi & \\
\hline Kata Kunci: & Kegiatan pengabdian ini dimulai dengan ditandai adanya anggapan \\
Media sosial, covid-19, & orangtua murid bahwa penggunaaan media sosial di masyarakat \\
masyarakat, desa & belum efektif, bijaksana dan produktif dalam proses pembelajarn di \\
& masa pandemi covid-19. Berdasarkan hal tersebut, kegiatan ini \\
& bertujuan untuk memberikan sosialisasi agar masyarakat mengetahui \\
& penggunaan media sosial bagi orangtua dan anak. Hasil dari kegiatan \\
& ini diperoleh bahwa tumbuhnya motivasi orangtua untuk mengetahui \\
& dan menggunakan berbagai jenis media sosial dan menumbuhkan \\
& kesadaran akan nilai produktivitas media sosial dalam mendukung \\
& program belajar di masa pandemi covid-19.
\end{tabular}

\section{PENDAHULUAN}

Alasan penulis melakukan PBP (Pengabdian Berbasis Penelitian) di MDTA (Madrasah Diniyah Takmiliyah Awaliyah) Desa Ciherang, karena rendahnya pembelajaran terutama pada keaktifan belajar. Hal ini dibuktikan dari peserta didik yang merasa jenuh ketika belajar, sebagian siswa tidur ketika belajar, kurang faham mengenai materi yang di ajarkan guru sehingga peserta didik bersikap apatis karena ketidakfahaman dari pelajaran tersebut, dan metode yang diajarkan atau disampaikan terkesan jenuh dan monoton.

Berangkat dari pemikiran tersebut, penulis bermaksud mengatasi kondisi tersebut dengan menggunakan media sosial, yang diangkat dalam judul penelitian "Pemanfaatan Media Sosial Pada Masyarakat Pedesaan Terhadap Kemajuan Pendidikan Islam".

Yang menjadi fokus penelitian penulis yang pertama bagaimana penggunaan media sosial di Desa Ciherang, yang kedua bagaimanakah jenis-jenis media sosial di masyarakat pedesaan, yang ketiga bagaimana penggunaan media sosial pada siswa MDTA Tarbiyatul Islam, dan yang keempat bagaimana pemanfaatan media sosial terhadap intensitas belajar siswa MDTA Tar biyatul Islam. Dengan adanya masalah tersebut maka tujuan penelitian ini yang pertama untuk mengetahui penggunaan media sosial di Desa Ciherang. Kedua, Untuk mengetahui jenis-jenis media sosial yang digunakan masyarakat pedesaan. Ketiga, Untuk mengetahui penggunaan media sosial pada siswa MDTA Tarbiyatul Islam. Dan ke empat, Untuk mengetahui pemanfaatan media sosial terhadap intensitas belajar siswa MDTA Tarbiyatul Islam.

\section{METODE}

Metode kegiatan ini dilaksanakan dengan cara sosialisasi, di mana penulis terlibat langsung dala proses sosialisasi tersebut, tepatnya di Desa Ciherang Kecamatan Pasawahan, Purwakarta dengan menadakan kegiatan diskusi. 


\section{HASIL DAN PEMBAHASAN}

\section{A. Hasil Kegiatan}

Mengabdikan diri kepada masyarakat menjadi penting ketika kita memiliki sesuatu yang layak dan berdampak baik untuk masyarakat sekitar khususnya, dalam PBP ini penulis melakukan pengabdian dan penelitian di Desa Ciherang untuk membantu meningkatkan kesadaran masyarakat pedesaan agar melek media sesuai Era 4.0 masyarakat tidak tertinggal kemajuan teknologi. Sehingga dari pengabdian dan penelitian ini penulis mendapatkan beberapa data dari observasi, wawancara. Diantaranya :

1) Wawancara dengan Kepala Desa Ciherang penulis mendapatkan data Desa Ciherang bahwa Jarak antara Pemerintahan Desa ke Ibu Kota Negara : $90 \mathrm{Km}$. Jarak anatara Pemerintahan Desa ke Ibu Kota Provinsi : 77 Km. Jarak antara Pemerintahan Desa ke Ibu Kota Kabupaten : 7 Km. Jarak antara Pemerintahan Desa ke Ibu Kota Kecamatan : $3 \mathrm{Km}$. Di Pemerintahan Desa Ciherang terdapat 3 Sekolah Dasar(SDN 1 CIHERANG, SDN 2 CIHERANG, SDN 3 CIHERANG) 1 Sekolah Menengah Pertama(SMP) SMP Negeri 3 Pasawahan. Dan terdapat 3 MDTA(MDTA Nurul Anwar, MDTA Tarbiyatul Islam, MDTA Nurul Huda). Selain itu penulis mengetahui struktur organisasi Pemerintahan Desa Ciherang serta kegiatan Desa seperti Minggon, Jumsih, dan pengajian di Majlis Taklim.

2) Wawancara dengan Sekretaris Desa Ciherang penulis mendapatkan data penggunaan media sosial di Desa Ciherang. Bahwa penggunaan media sosial di masyarakat Desa Ciherang terdiri dari masyarakat pedesaan, pelajar, tokoh agama, dan tokoh pendidikan. Dengan penggunaan media sosial tersebut masyarakat desa ciherang jadi melek media dan tidak terrtinggal kemajuan teknologi.

3) Wawancara dengan Tokoh Pemuda, penulis mendapatkan data jenis-jenis media sosial yang digunakan di masyarakat pedesaan seperti facebook, Twitter dan Youtube, Google Plus. Dengan penggunaan media sosial tersebut masyarakat mengubah pengalaman mereka dan berinteraksi dengan jejaring internet dalam kehiduan sehari-hari.

4) Wawancara dengan Tokoh Masyarakat penulis mendapatkan data jenis media sosial yang digunakan masyarakat Desa Ciherang pada umumnya adalah Youtube. Sehingga masyarakat lebih mudah mendapatkan informasi perubahan kehidupan, misalnya kemajuan pendidikan, keagamaan, sosial. Dengan itu masyarakat bisa lebih fleksibel dalam menentukan arah perubahan dalam kehidupannya.

5) Wawancara dengan Tokoh Agama, penulis mendapatka data bahwa siar keislaman takkan berkembang jika tidak ditunjang dengan pemanfaatan media sosial. Diantaranya melalui Youtube siar keagamaan akan mudah tersampaikan kepada masyarakat.

6) Wawancara dengan Tokoh Pendidikan penulis mendapatkan data penggunaan media sosial pada siswa di MDTA Tarbiyatul Islam. Bahwa dengan menggunakan media (Youtube) materi belajar akan mudah tersampaikan dan dipahami oleh siswa. Dengan itu kegiatan belajar mengajar lebih termenej dengan baik sehingga materi yang disampaikan mudah diterima dan difahami siswa.

7) Wawancara dengan Kepala Madrasah MDTA Desa Ciherang, penulis mendapatkan data jumlah siswa di MDTA Tarbiyatul Islam yakni sebanyak 180 siswa. Media belajar yang digunakan dalam kegiatan belajar mengajar masih menggunakan media sederhana, seperti menggunakan black board. Sehingga penulis memberikan saran menggunakan 
media sosial Youtube sehingga media sosial tersebut dapat membantu kelancaran kegiatan belajar.

8) Wawancara dengan staf guru MDTA Tarbiyatul Islam Desa Ciherang penulis mendapatkan data intensitas belajar siswa di MDTA Tarbiyatul Islam. Penulis memberikan motivasi siswa dan guru agar semangat belajar dengan cara menggunakan media sosial Youtube(mengetahui sejarah islam dengan luas), dengan memberikan media lainnya seperti memberikan dazoman yang memperkuat pengetahuan siswa pada sejarah islam. Sehingga staf guru di MDTA Tarbiyatul islam akan mencapai hasil pembelajaran yang baik pada siswanya.

Kesimpulan dari pertanyaan kepada setiap responden diatas masyarakat Desa Ciherang telah memahami pemanfaatan media sosial dengan baik. Kepala Desa Ciherang, menyatakan Dengan penggunaan media sosial tersebut masyarakat Desa Ciherang jadi melek media dan tidak tertinggal kemajuan teknologi. Sekretaris Desa Ciherang, menyatakan Bahwa penggunaan media sosial di masyarakat Desa Ciherang terdiri dari masyarakat pedesaan, pelajar, tokoh agama, dan tokoh pendidikan. Dengan penggunaan media sosial tersebut masyarakat Desa Ciherang akan mudah mendapatkan informasi kemajuan zaman dengan baik. Tokoh Pemuda meyatakan Dengan penggunaan media sosial tersebut masyarakat mengubah pengalaman mereka dan berinteraksi dengan jejaring internet dalam kehiduan sehari-hari. Tokoh Masyarakat menyatakan bahwa masyarakat lebih mudah mendapatkan informasi perubahan kehidupan, misalnya kemajuan pendidikan, keagamaan, sosial. Dengan itu masyarakat bisa lebih fleksibel dalam menentukan arah perubahan dalam kehidupannya. Tokoh Agama menyatakan dengan media sosial siar keagamaan akan mudah tersampaikan kepada masyarakat. Tokoh Pendidikan menyatakan Dengan media sosial kegiatan belajar mengajar lebih termenej dengan baik sehingga materi yang disampaikan mudah diterima dan difahami siswa. Kepala MDTA Tarbiyatul Islam menyatakan bahwa media sosial tersebut dapat membantu kelancaran kegiatan belajar. Staf guru di MDTA Tarbiyatul islam menyatakan bahwa dengan media sosial guru akan mencapai keberhasilan pembelajarannya dengan baik pada siswanya.

Penulis menyimpulkan bahwa masyarakat Desa Ciherang, mulai dari tokoh agama, tokoh masyarakat, tokoh pemuda, tokoh pendidikan, serta lingkungan masyarakat Desa Ciherang khususnya di MDTA Tarbiyatul Islam dapat memanfaatkan media sosial dengan baik dan benar.

\section{B. Pembahasan}

Kepala Desa Ciherang menyampaikan bahwa Desa Ciherang adalah salah satu dari 12 desa yang ada di Kecamatan Pasawahan, Kabupaten Purwakarta, Provinsi Jawa Barat yang terletak $3 \mathrm{Km}$ ke arah barat dari kota Kecamatan Pasawahan dengan luas wilayah 131.531 Ha. Adapun batas wilayah administaratif Pemerintah Desa Ciherang di sebelah Utara : Desa Cidahu, Kecamatan Pasawahan. Di sebelah Timur : Desa Pasawahan Anyar, Kecamatan Pasawahan dan Desa Situ Kecamatan Pondok Salam. Di sebelah Selatan : Desa Parakan Lima, Kecamatan Jatiluhur. di sebelah Barat : Desa Parakan Lima, Kecamatan Jatiluhur. di sebelah Barat: Desa Parakan Lima, Kecamatan Jatiluhur. 
Jarak antara Pemerintahan Desa ke Ibu Kota Negara : $90 \mathrm{Km}$. Jarak anatara Pemerintahan Desa ke Ibu Kota Provinsi : 77 Km. Jarak antara Pemerintahan Desa ke Ibu Kota Kabupaten : 7 Km. Jarak antara Pemerintahan Desa ke Ibu Kota Kecamatan : 3 Km.

Bentang wilayah Desa Ciherang terdiri dari dataran rendah, berbukit-bukit, dataran tinggi, dan aliran sungai dengan ketinggian 125-232 meter diatas permukaan laut.

Di Pemerintahan Desa Ciherang terdapat 3 Sekolah Dasar yakni : SDN 1 CIHERANG di Kp.Tanjung Kerta Rt 01/01. SDN 2 CIHERANG di Kp.Ciherang Tonggoh Rt 11/03. SDN 3 CIHERANG di Kp.Pasir Muncang Rt. Terdapat 1 Sekolah Menengah Pertama yakni : SMP Negeri 3 Pasawahan di Kp.Tanjung Kerta Rt 03/01. Dan di Desa Ciherang terdapat 3 MDTA (Madrasah Diniyah Takmiliyah Awaliyah) yakni : MDTA Nurul Anwar di Kp.Tanjung Kerta Rt 01/01, MDTA Tarbiyatul Islam di Kp.Ciherang Tonggoh Rt 08/06, dan MDTA Nurul Huda di Kp.Pasir Muncang Rt 19/05. ${ }^{1}$ Dari itu bahwa penggunaan media sosial di masyarakat Desa Ciherang sangat banyak dan pemanfaatan media sosial sangat berpengaruh bagi kemajuan Desa Ciherang.

Media sosial adalah sebuah media online, dengan para penggunanya bisa dengan mudah berpartisipasi, berbagi, dan menciptakan isi meliputi blog, jejaring sosial, wiki, forum dan dunia virtual. Blog, jejaring sosial dan wiki merupakan bentuk media sosial yang paling umum digunakan oleh masyarakat di seluruh dunia. Pendapat lain mengatakan bahwa media sosial adalah media online yang mendukung interaksi sosial dan media sosial menggunakan teknologi berbasis web yang mengubah komunikasi menjadi dialog interaktif. Media Sosial (Social Media) adalah saluran atau sarana pergaulan sosial secara online di dunia maya (internet). Para pengguna (user) media sosial berkomunikasi, berinteraksi, saling kirim pesan, dan saling berbagi (sharing), dan membangun jaringan (networking). ${ }^{2}$

Berdasarkan data yang saya dapatkan dari Kepala Desa dan arsip desa pengunaan media sosial di Desa Ciherang untuk aparat desa, sejalan dengan teori para ahli, Desa Ciherang sudah baik dalam memanfaatkan media sosial, namun belum maksimal implementasinya di ranah pendidikan.

Jenis media sosial yang populer digunakan masyarakat Indonesia khusunya pada masyarakat pedesaan diantaranya Facebok, Twitter, Youtube, Blog, Google Plus. Sebagai salah satu media komunikasi, media sosial tidak hanya dimanfaatkan untuk berbagi informasi dan inspirasi, tapi juga ekspresi diri (self expression). Dan jenis media sosial yang digunakan penulis dalam pengabdian dan penelitian ini adalah Youtube. Selain masyarakat melek media sosial juga pengetahuan masyarakat lebih terarah dengan baik.

Media sosial merupakan alat promosi bisnis yang efektif karena dapat diakses oleh siapa saja, sehingga jaringan promosi bisa lebih luas. Media sosial menjadi bagian yang sangat diperlukan oleh pemasaran bagi banyak perusahaan dan merupakan salah satu cara terbaik untuk menjangkau pelanggan dan klien. Media sosial sperti blog, facebook, twitter, dab youtube memiliki sejumlah manfaat bagi perusahaan dan lebih cepat dari media konvensional seperti media cetak dan iklan TV, brosur dan selebaran.

\footnotetext{
1 Wijaya Rukma,2020. Observasi Pemerintahan Desa Ciherang. Kecamatan Pasawahan, Kabupaten Purwakarta.

2 Putra, Jaya. 2012. Pengertian Media sosial peran serta fungsinya. http://jayaputrasbloq.blogspot.com/2011/02/definisi-atau-pengertian-istilah-social.html, diakses 7 Agustus 2017
} 
Media sosial memiliki kelebihan dibandingkan dengan media konvensional, antara lain :

a. Kesederhanaan Dalam sebuah produksi media konvensional dibutuhkan keterampilan tingkat tinggi dan keterampilan marketing yang unggul. Sedangkan media sosial sangat mudah digunakan, bahkan untuk orang tanpa dasar TI pun dapat mengaksesnya, yang dibutuhkan hanyalah komputer dan koneksi internet.

b. Membangun Hubungan Sosial media menawarkan kesempatan tak tertandingi untuk berinteraksi dengan pelanggan dan membangun hubungan. Perusahaan mendapatkan sebuah feedback langsung, ide, pengujian dan mengelola layanan pelanggan dengan cepat. Tidak dengan media tradisional yang tidak dapat melakukan hal tersebut, media tradisional hanya melakukan komunikasi satu arah.

c. Jangkauan Global Media tradisional dapat menjangkau secara global tetapi tentu saja dengan biaya sangat mahal dan memakan waktu. Melalui media sosial, bisnis dapat mengkomunikasikan informasi dalam sekejap, terlepas dari lokasi geografis. Media sosial juga memungkinkan untuk menyesuaikan konten anda untuk setiap segmen pasar dan memberikan kesempatan bisnis untuk mengirimkan pesan ke lebih banyak pengguna.

d. Terukur dengan system tracking yang mudah, pengiriman pesan dapat terukur, sehingga perusahaan langsung dapat mengetahui efektifitas promosi. Tidak demikian dengan media konvensional yang membutuhkan waktu yang lama. ${ }^{3}$

Dari hasil diatas maka penggunaan media sosial di masyarakat Desa Ciherang terdiri dari masyarakat pedesaan, pelajar, tokoh agama, dan tokoh pendidikan. Dengan penggunaan media sosial tersebut masyarakat Desa Ciherang akan mudah mendapatkan informasi kemajuan zaman dengan baik.

Media sosial dalam dunia pendidikan secara fungsinya dikondisikan sebagai bentuk kolaborasi, keramahan, dan kreatifitas penggunanya. Kondisi yang terjadi di masyarakat pedesaan, banyak kalangan masyarakat belum menyadari pentingnya kebutuhan sosial media dan internet dalam dunia pendidikan. Penggunaan media sosial dalam dunia pendidikan dirasakan belum dipandang istmewa. (Suci Nurpratiwi, Muhamad Ridwan Effendi, 2021) Namun setelah masyarakat mengetahui pemanfaatan media sosial dalam dunia pendidikan, Media belajar dipandang penting dimanfaatkan dengan baik guna mengarah ke jenjang pendidikan yang lebih tinggi. Media sosial memiliki daya tariknya sendiri bagi setiap kalangan, begitu pula dengan siwa di MDTA Tarbiyatul Islam. Selama pengabdian penulis menyaksikan bagaimana media sosial dengan sangat mudah mempengaruhi karakter dan pengetahuan siswa, yang awalnya siswa hanya menggunakan media sosial hanya sebatas hiburan, Kini siswa menggunakan media sosial dengan menonton aneka ragam tuntunan keislaman dan pendidikan di Youtube yang bermanfaat untuk menambah kekuatan akhlaknya serta menambah pengetahuannya.

Proses belajar merupakan sebuah proses penyampaian informasi, ilmu pengetahuan, informasi yang secara formal dan informal sering terjadi di sekeliling kita. Proses belajar

\footnotetext{
3 Putra, Jaya. 2012. Pengertian Media sosial peran serta fungsinya. http://jayaputrasbloq.blogspot.com/2011/02/definisi-atau-pengertian-istilah-social.html, diakses 7 Agustus 2017
} 
merupakan sebuah kondisi mengenai kapasitas individu untuk mengetahui lebih luas. Melalui sebuah media sosial, pengetahuan dan proses belajar tidak lagi hanya berfokus pada akumulasi pengetahuan individu sebelumnya. Terlepas dari baik ataukah buruk, menggunakan media tersebut sebagai media dalam proses belajar, maka jelas bahwa aplikasi dan perangkat media sosial telah berhasil menyediakan sebuah konsep tantangan baru dalam pembentukan pendidikan formal yang telah ada saat ini. Pemanfaatan media sosial sebagai media belajar telah menunjang sebuah teori klasik mengenai teori pembelajaran sosial. Teori ini mengatakan bahwa proses belajar sosial berfokus pada bagaimana seorang individu belajar dengan menjadikan orang lain sebagai subjek belajarnya. proses belajar ini telah ditunjang oleh media digital seperti bagaimana seseorang belajar menggoreng telur dengan melihat video orang lain menggoreng telur. Selain belajar mengenai sebuah perilaku sederhana mengenai keahlian seseorang, dalam media sosial dapat pula ditemukan bagaimana seorang individu belajar dan mulai memikirkan konsekuensi yang akan timbul dari perilaku yang dilakukan oleh subjek belajarnya. Media sosial pada kelanjutannya tidak hanya mengajarkan bagaimana sebuah teknologi komunikasi dan informasi memberikan dampak, tetapi juga mengajarkan bagaimana sebuah teknologi komunikasi diserap dan diadopsi. Pemanfaatan Media sosial kini banyak terjadi pada proses pendidikan jarak jauh (elearning) di mana proses belajar mengajar tidak lagi terbatas pada ruang kelas, jarak, dan waktu.

Media sosial memiliki daya tariknya sendiri bagi setiap kalangan, begitupula dengan kalangan remaja. Berdasarkan hasil riset yang dilakukan oleh kementrian Kominfo dalam penelusuran para pengguna aktivitas online pada anak usia remaja tahun 2014, ditarik kesimpulan bahwa penggunaan media sosial sangat melekat dengan kehidupan remaja sehari-hari. Daya tarik internet dan media sosial inilah yang kemudian memegang peranan penting dalam membangun kemampuan berkomunikasi seseorang. Remaja saat ini begitu peka dengan perubahan yang terjadi dalam teknologi sosial, mereka mengikuti perkembangan tersebut dan menguasainya. Jaringan sosial seperti Facebook, Twitter dan YouTube telah cepat menjadi bagian dari kehidupan Anda sehari-hari. Salah satu alasan mengapa media sosial sangat populer adalah karena memungkinkan pengguna untuk mengubah pengalaman mereka dan berinteraksi dengan jaringan internet. Dengan banyaknya teknologi baru dan perkembangan jaringan sosial saat ini, ada banyak manfaat dan alasan bagi semua orang, termasuk pelajar atau mahasiswa untuk menggunakan media sosial. Sebuah penelitian menemukan hasil bahwa 70\% pelajar merasa bahwa teknologi yang mereka gunakan untuk belajar harus disesuaikan dengan diri mereka sebagai pengguna media sosial. Berikut manfaat penggunaan media sosial untuk pendidikan diantaranya mendukung bateri Pembelajaran media sosial dapat membantu mengidentifikasikan konten tambahan untuk memperkuat atau memperluas pembelajaran pelajar. Misalnya saja YouTube membantu menyediakan video bagi pelajar secara audio visual ketika dibutuhkan untuk memperjelas materi pembelajaran. Media sosial memungkinkan pelajar mengirimkan bermacam-macam dokumen seperti video, reminder, voice note, gambar, data dan lainnya. ${ }^{4}$ Motivasi belajar adalah dorongan yang timbul dari dalam diri siswa(instrinsik) dan dari luar diri siswa(ekstrinsik) untuk melakukan sesuatu. Motivasi instrinsik meliputi hasrat dan keinginan untuk berhasil, dorongan kebutuhan belajar, dan harapan akan cita-cita siswa.

4 Nugraha, Abrianto. 2012.Manfaat Media Sosial dalam Dunia Pendidikan. https://abriantonugraha.wordpress.com/, tanggal 16 Desember 2017. 
Sedangkan motivasi ekstrinsik yang meliputi adanya penghargaan, lingkungan belajar yang kondusif, kegiatan belajar yang menarik, dan adanya upaya guru dalam membelajarkan siswa. $^{5}$

Berdasarkan simpulan diatas maka pengunaan media sosial di MDTA dipandang baik karena masyarakat Desa Ciherang sudah memandang penggunaan media sosial dalam pendidikan itu penting. Sejalan dengan teori Abrianto Nugraha yang menyatakan bahwa proses belajar sosial berfokus pada bagaimana seorang individu belajar dengan menjadikan orang lain sebagai subjek belajarnya. proses belajar ini telah ditunjang oleh media digital seperti bagaimana seseorang belajar menggoreng telur dengan melihat video orang lain menggoreng telur. Selain belajar mengenai sebuah perilaku sederhana mengenai keahlian seseorang, dalam media sosial dapat pula ditemukan bagaimana seorang individu belajar dan mulai memikirkan konsekuensi yang akan timbul dari perilaku yang dilakukan oleh subjek belajarnya. Dengan pengabdian ini penulis melihat peningkatan motivasi belajar siswa MDTA Tarbiyatul Islam dengan baik.

Sebagian siswa MDTA Tarbiyatul islam yang kecanduaan menggunakan media sosial tanpa mengenal waktu sehingga menurunkan produktifitas dan rasa sosial diantara temannya pun berkurang. Maka penulis memberikan arahan agar penggunaan media sosial pada siswa di MDTA Tarbiyatul Islam dimanfaatkan dengan baik untuk belajar. Penulis menggunakan media sosial Youtube dalam pelaksanaan kegiatan belajar mengajar di MDTA Tarbiyatul Islam untuk meningkatkan semangat belajar siswa.

Dalam Ruang Guruku(informasi pendidikan), Media pembelajaran adalah alat sarana atau perantara yang digunakan dalam prosese interaksi yang berlangsung antara guru dan siswa untuk mendorong terjadinya proses belajar mengajar dengan tujuan untuk memperoleh pengetahuan, keterampilan serta memantapkan apa yang dipelajari dan membantu untuk mencapai tujuan pembelajaran yang berkualitas.

Menurut pandangan Skinner Belajar adalah suatu perilaku pada saat orang belajar, maka responnya menjadi lebih baik. Sebaliknya, bila ia tidak belajar maka responnya menurun. Menurut Abrianto Nugraha dalam buku(Manfaat Media Sosial Dalam Dunia Pendidikan) media sosial memiliki daya tariknya sendiri bagi setiap kalangan, begitu pula dengan kalangan remaja. Daya tarik internet dan media sosial inilah yang kemudian memegang peranan penting

dalam membangun kemampuan berkomunikasi seseorang. Remaja saat ini begitu peka dengan perubahan yang terjadi dalam teknologi sosial, mereka mengikuti perkembangan tersebut dan menguasainya. Misalnya saja Youtube membantu menyediakan video bagi pelajar secara audio visual ketika dibutuhkan untuk memperjelas materi pembelajaran.

Berdasarkan uraian di atas, dapat disimpulkan bahwa Belajar menurut pandangan Skinner adalah bila seseorang belajar maka responnya akan baik, karena belajar merupakan suatu perilaku pada saat seseorang itu belajar. Sedangkan apabila seseorag tidak belajar maka responnya menurun. Dan Manfaat Media Sosial Bagi Pelajar menurut Abrianto Nugraha adalah pelajar akan faham akan materi pembelajaran yang disampaikan. Begitu pula peneliti mendapatkan data bahwa dengan memanfaatkan media sosial dalam belajar mengajar di MDTA Tarbiyatul Islam mengetahui adanya peningkatan terhadap intensistas belajar siswa.

\footnotetext{
${ }^{5}$ https://www.rijal09.com/2016/03/motivasi-belajar.html?m=1
} 
Ditinjau dari teori Skiner dan Abrianto Nugraha serta hasil dilapangan seirama menyatakan bahwa penggunaan media sosial dalam dunia pendidikan khususnya di MDTA Tarbiyatul Islam perlu diterapkan karena penggunaan media sosial memberikan motivasi belajar dengan baik.

Tabel 1. Rancangan kegiatan Pengabdian kepada Masyarakat

\begin{tabular}{|c|c|c|c|c|c|c|}
\hline NO. & $\begin{array}{c}\text { NAMA } \\
\text { KEGIATAN }\end{array}$ & $\begin{array}{c}\text { TGL/ } \\
\text { BULAN/ } \\
\text { TAHUN } \\
\end{array}$ & $\begin{array}{l}\text { TEMPAT } \\
\text { KEGIATAN }\end{array}$ & $\begin{array}{c}\text { TEMA } \\
\text { KEGIATAN }\end{array}$ & $\begin{array}{c}\text { NAMA/ } \\
\text { JABATAN } \\
\text { NARASUMBER } \\
\end{array}$ & $\begin{array}{c}\text { MAKSUD DAN } \\
\text { TUJUAN } \\
\text { KEGIATAN } \\
\end{array}$ \\
\hline 1. & $\begin{array}{l}\text { Pelaksanaan } \\
\text { PBP/KPM }\end{array}$ & $\begin{array}{l}22 \text { Oktober }-30 \\
\text { November } \\
2020\end{array}$ & Desa Ciherang & $\begin{array}{l}\text { Pengabdian } \\
\text { dan } \\
\text { Penelitian di } \\
\text { Desa } \\
\text { Ciherang }\end{array}$ & $\begin{array}{l}\text { Rukma Wijaya } \\
\text { (Kepala Desa } \\
\text { Ciherang), } \\
\text { Sarip Saprudin } \\
\text { (Sekretaris Desa } \\
\text { Ciherang. }\end{array}$ & $\begin{array}{l}\text { MPP } \\
\text { mendapatkan } \\
\text { data Desa dan } \\
\text { penggunaan } \\
\text { media sosial di } \\
\text { Desa Ciherang. }\end{array}$ \\
\hline 2. & $\begin{array}{l}\text { Melaksanaka } \\
\text { n Kegiatan } \\
\text { PBP/KPM di } \\
\text { Lingkungan } \\
\text { Desa } \\
\text { Ciherang }\end{array}$ & $\begin{array}{l}2 \text { November } \\
2020 \text { dan } 7 \\
\text { November } \\
2020\end{array}$ & $\begin{array}{l}\text { Di Lingkungan } \\
\text { MasyarakatDes } \\
\text { a Ciherang }\end{array}$ & $\begin{array}{l}\text { Observasi, } \\
\text { wawancara, } \\
\text { kepada tokoh } \\
\text { pemuda, } \\
\text { tokoh } \\
\text { masyarakat } \\
\text { di Desa } \\
\text { Ciherang }\end{array}$ & $\begin{array}{l}\text { Ali Ruyani, S.Pd } \\
\text { (Tokoh Pemuda), } \\
\text { Bapak H. Ganda } \\
\text { (Tokoh } \\
\text { Masyarakat). }\end{array}$ & $\begin{array}{l}\text { MPP } \\
\text { mendapatkan } \\
\text { data jenis-jenis } \\
\text { media sosial di } \\
\text { masyarakat } \\
\text { pedesaan. }\end{array}$ \\
\hline 3. & $\begin{array}{l}\text { Melaksanaka } \\
\text { n Kegiatan } \\
\text { PBP/KPM di } \\
\text { Lingkungan } \\
\text { Desa } \\
\text { Ciherang }\end{array}$ & $\begin{array}{l}3 \text { November } \\
\text { dan } 8 \\
\text { November } \\
2020\end{array}$ & $\begin{array}{l}\text { Di Lingkungan } \\
\text { Masyarakat } \\
\text { Desa Ciherang }\end{array}$ & $\begin{array}{l}\text { Observasi, } \\
\text { wawancara, } \\
\text { kepada tokoh } \\
\text { agama, tokoh } \\
\text { pendidikan } \\
\text { di Desa } \\
\text { Ciherang }\end{array}$ & $\begin{array}{l}\text { M. Sanusi } \\
\text { (Tokoh Agama), } \\
\text { Ali Ruyani, S.Pd } \\
\text { (Tokoh } \\
\text { Pendidikan). }\end{array}$ & $\begin{array}{l}\text { MPP } \\
\text { mendapatkan } \\
\text { data } \\
\text { penggunaan } \\
\text { media sosial } \\
\text { pada siswa di } \\
\text { MDTA } \\
\text { Tarbiyatul } \\
\text { Islam. } \\
\end{array}$ \\
\hline 4. & $\begin{array}{l}\text { Melaksanaka } \\
\text { n Kegiatan } \\
\text { PBP/KPM di } \\
\text { MDTA } \\
\text { Tarbiyatul } \\
\text { Islam Desa } \\
\text { Ciherang }\end{array}$ & $\begin{array}{l}9,10,11,12 \text {, } \\
14,17,22 \\
\text { November } \\
2020\end{array}$ & $\begin{array}{l}\text { Di Lingkungan } \\
\text { Masyarakat } \\
\text { Desa Ciherang }\end{array}$ & $\begin{array}{l}\text { Observasi, } \\
\text { wawancara, } \\
\text { kepada } \\
\text { kepala MDTA } \\
\text { Tarbiyatul } \\
\text { Islam, Guru } \\
\text { beserta siswa } \\
\text { MDTA } \\
\text { Tarbiyatul } \\
\text { Islam. }\end{array}$ & $\begin{array}{l}\text { Kepala Madrasah } \\
\text { MDTA Tarbiyatul } \\
\text { Islam } \\
\text { (Bapak Ustadz. Ijen } \\
\text { Juaeni) } \\
\text { Guru Madrasah } \\
\text { MDTA Tarbiyatul } \\
\text { Islam } \\
\text { (Ustadz M. Sanusi } \\
\text { \& Ustadz Affan). } \\
\text { Beserta siswa } \\
\text { MDTA Tarbiyatul } \\
\text { Isam. } \\
\end{array}$ & $\begin{array}{l}\text { MPP } \\
\text { mendapatkan } \\
\text { data intensitas } \\
\text { belajar siswa di } \\
\text { MDTA } \\
\text { Tarbiyatul } \\
\text { Islam. }\end{array}$ \\
\hline
\end{tabular}


SIVITAS, Vol. 1. No. 1 Januari 2021, 28 - 39

Gambar 1. (a)sosialisasi pembekalan pbp/kpm 2020 (b)bimbingan pelaksanaan pbp/kpm dengan dosen pembimbing (c)wawancara dengan kepala desa ciherang (d)wawancara dengan sekretasis desa ciherang
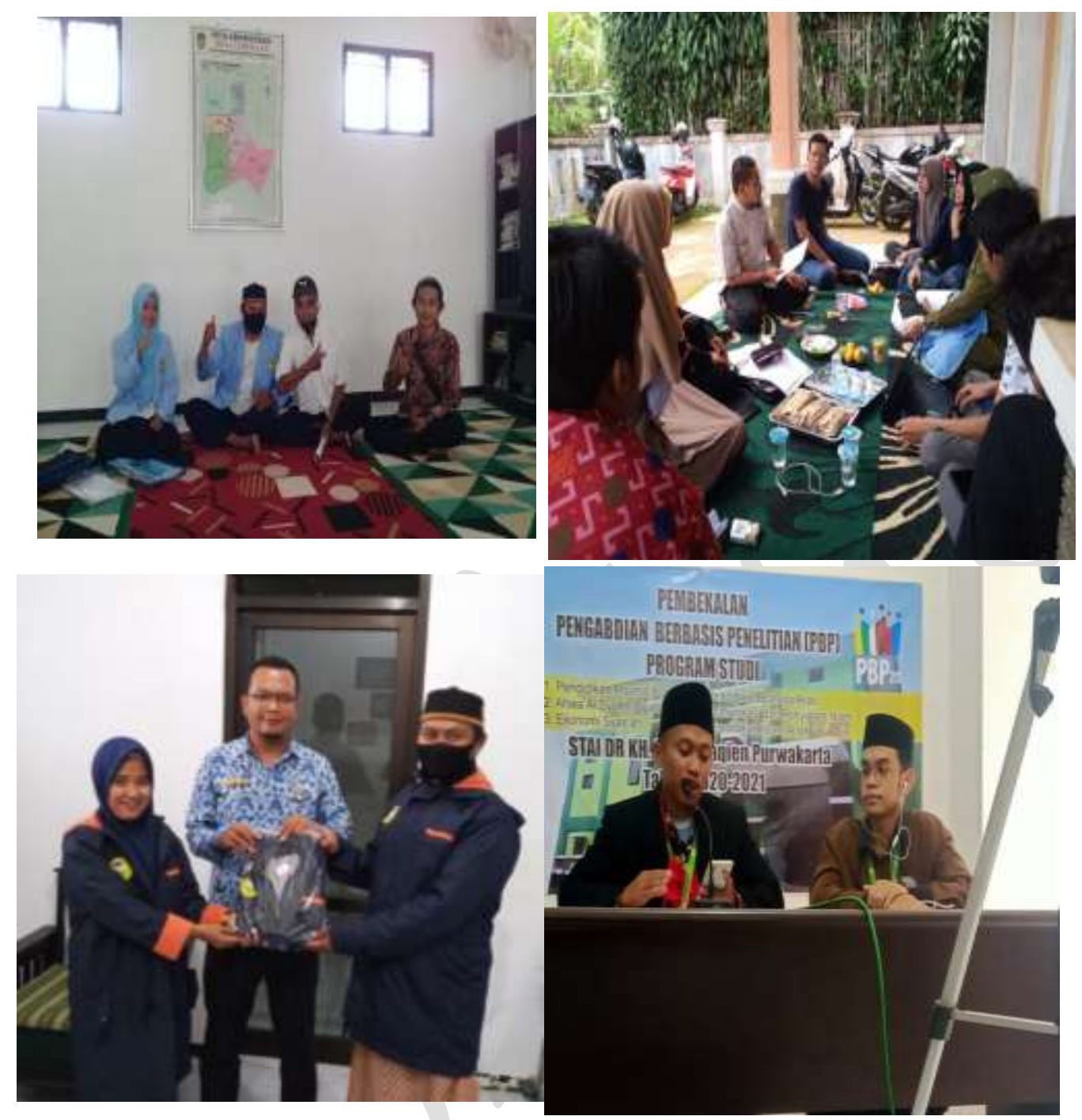
Sosialisasi Pemanfaatan Media Sosial ... (Irma Yanti)

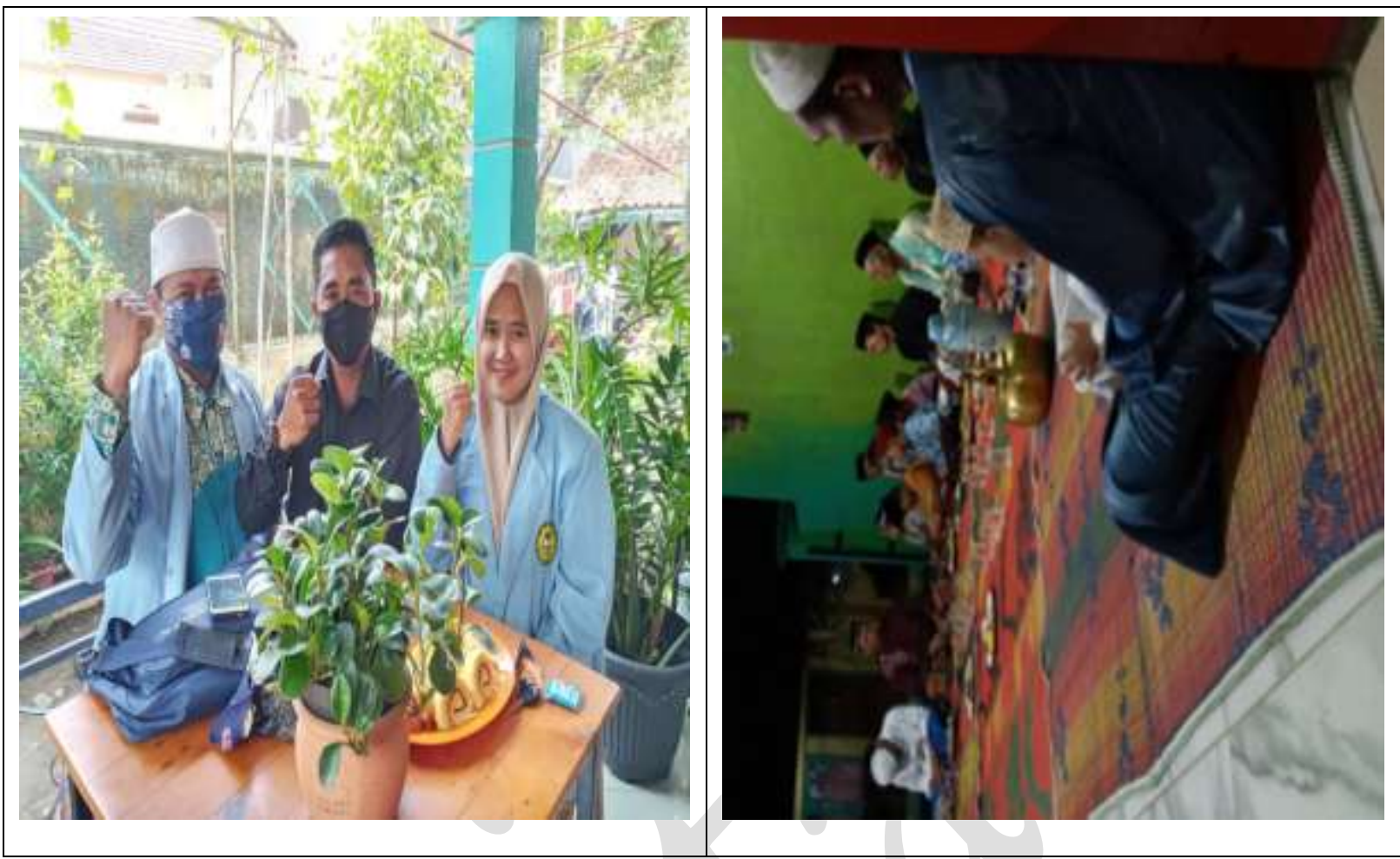

Gambar 2. (a)wawancara dengan tokoh pemuda (b)wawancara dengan tokoh masyarakat

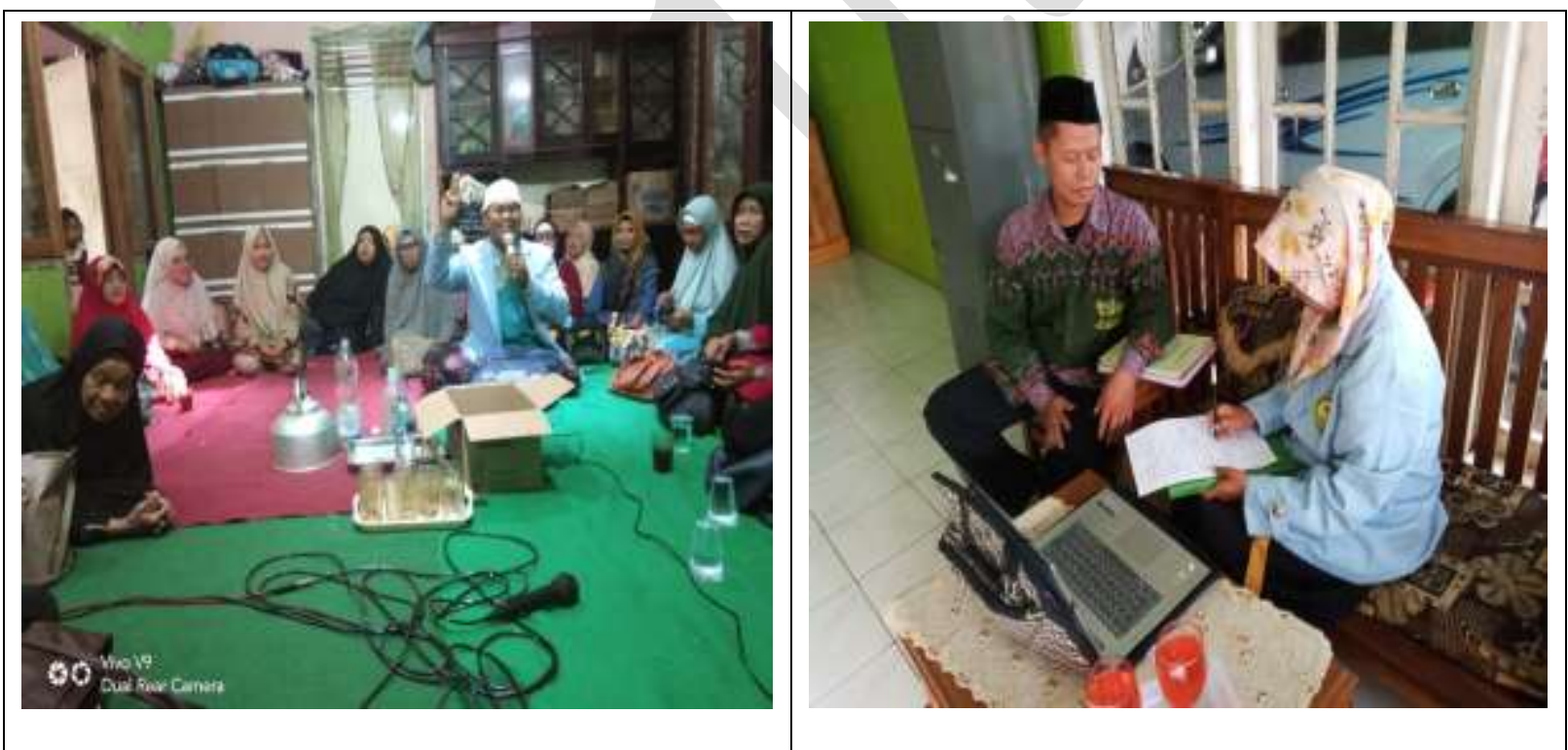

Gambar 3. (a)wawncara dengan tokoh agama (b)wawancara dengan tokoh pendidikan 


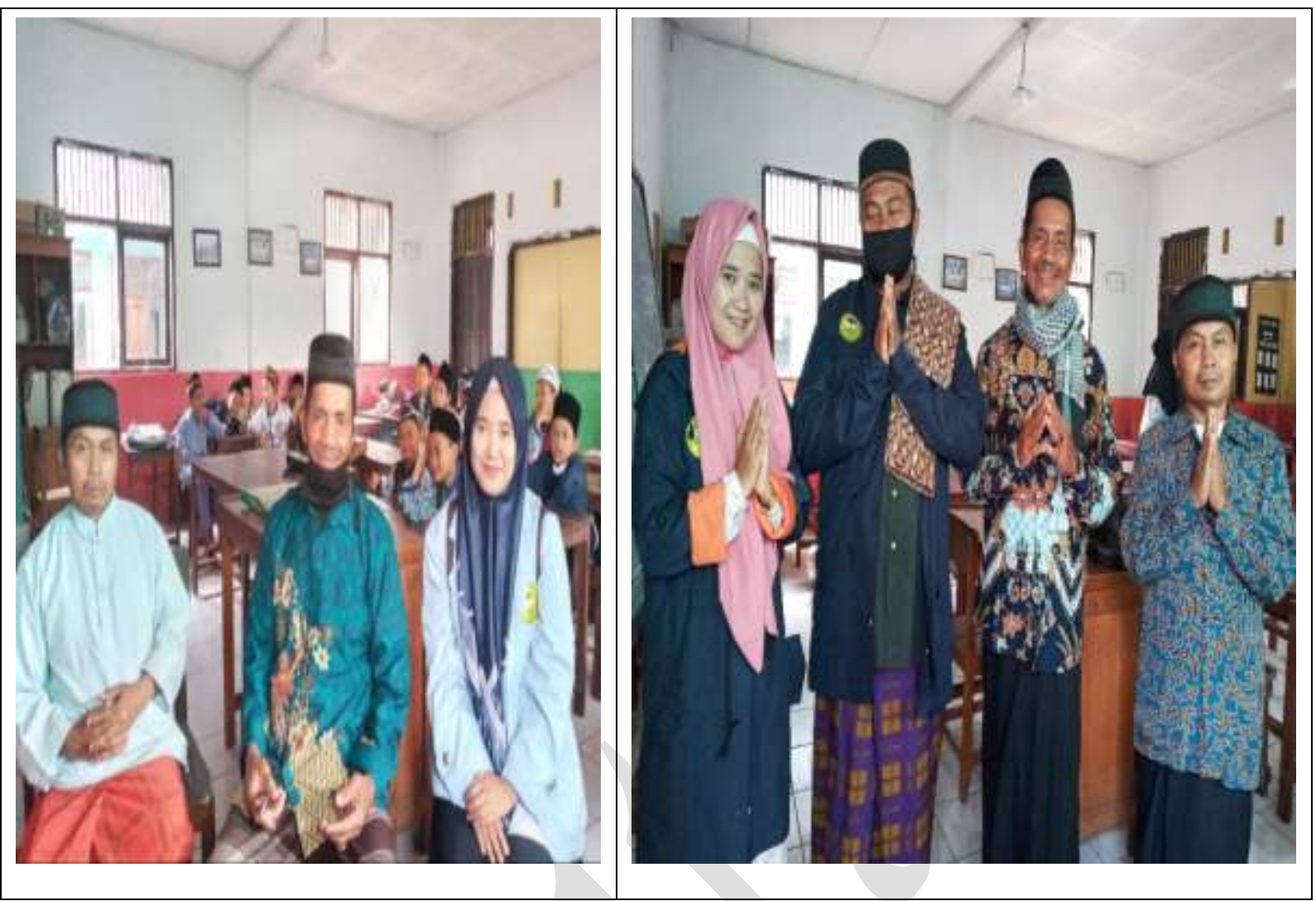

Gambar 4. (a)wawancara dengan kepala MDTA Tarbiyatul Islam(b)wawancara dengan guru MDTA Tarbiyatul Islam

\section{KESIMPULAN}

Setelah observasi penulis menemukan rendahnya pembelajaran terutama pada keaktifan belajar. Hal ini dibuktikan dari peserta didik yang merasa jenuh ketika belajar. Tujuan penelitian ini agar masyarakat mengetahui penggunaa media sosial. Penulis beranggapan dengan adanya penggunaaan media sosial masyarakat menyadari manfaat media sosial bagi masyarakat pedesaan. Metode penelitian yang digunakan penulis adalah kualitatif deskriptif dengan observasi, wawancara. Hasil dari penelitian ini untuk mengetahui bagaimana penggunaan media sosial di masyarakat pedesaan. Sehingga dari pemanfaatan media sosial ini diperoleh hasil meningkatnya motivasi belajar siswa, keaktifan guru dalam mengajar, siswa mengetahui berbagai jenis media sosial, serta mengetahui penggunaan media sosial di sekolah.

\section{DAFTAR PUSTAKA}

Abdussalam, Huzaifah. 2015. Dampak positif dan negatif media sosial bagi Pelajar.

Effendi, M. R., \& Syafrudin, I. (2020). Pertalian Agama Pada Pilkada DKI Jakarta Tahun 2017. Jurnal Ilmiah Mimbar Demokrasi, 19(02), 12-27.

Effendi, M. R. Kata Kunci. 
Gemilang (Peter Salim dan Yeni Salim, Kamus Besar Kontemporer . Jakarta: Modern English https://abriantonugraha.wordpress.com/, tanggal 16 Desember 2017. http://SOSMED/Abdus\%20Salaam_\%20Dampak\%20Media\%20Sosial\%20Bagi\%20Pela jar.html, tanggal 12 Desember 2017.

Nugraha, Abrianto. 2012. Manfaat Media Sosial dalam Dunia Pendidikan.

Nurhalimah, Sitti. 2019. Media Sosial dan Masyarakat Pesisir : Refleksi Pemikiran Mahasiswa Bidikmisi. DEEPUBLISH

Putra, Jaya. 2012. Pengertian Media sosial peran serta fungsinya.

http://jayaputrasbloq.blogspot.com/2011/02/definisi-atau-pengertian-istilahsocial.html, diakses 7 Agustus 2017

Suci Nurpratiwi, Muhamad Ridwan Effendi, A. (2021). Improving Religious Literacy Through Islamic Religious Education Course Based On The Flipped Classroom. Istawa, 6(1), 1629. https://doi.org/http://dx.doi.org/10.24269/ijpi.v6i1.3107

S Nurpratiwi, MR Effendi, A Amaliyah - Istawa: Jurnal Pendidikan Islam, 2021

Susanto, Heri \& Akmal, Helmi. 2018. Efektivitas Penggunaan Aplikasi Pembelajaran Berbasis Mobile Smartphone Sebagai Media Pengenalan Sejarah Lokal Masa Revolusi Fisik Di Kalimantan Selatan Pada Siswa Sekolah Menengah Atas. HISTORIA: Jurnal Program Studi Pendidikan Sejarah, 6(2), 197-206.

Thobroni, Muhammad and Arif Mustofa, Belajar dan Pembelajaran, $2^{\text {nd }}$ edition (Jogjakarta: ArRuzz Media, 2013) 